
ISSN : 2615-1995, E-ISSN : 2615-0654

J. Madani., Vol. 3, No. 2, September 2020 (238 - 247)

(C)2018 Lembaga Kajian Demokrasi

dan Pemberdayaan Masyarakat (LKD-PM)

DOI : https://doi.org/10.33753/madani.v3i2.111

\title{
Pengaruh Likuiditas dan Profitabilitas Terhadap Struktur Modal PT Duta Anggada Realty Tahun 2008-2017
}

\author{
Hestu Nugroho Warasto \\ Fakultas Ekonomi, Universitas Pamulang \\ dosen01848@unpam.ac.id \\ Nining Setyaningsih \\ Fakultas Ekonomi, Universitas Pamulang \\ niningsetiyaningsih1@gmail.com
}

\begin{abstract}
Abstrak
Penelitian ini bertujuan untuk mengetahui Pengaruh Current Ratio dan Return On Asset Terhadap Debt to Equity Ratio Pada PT Duta Anggada Realty. Metode yang digunakan adalah explanatory research. Pengujian regresi, korelasi, determinasi dan uji hipotesis merupakan teknik yang digunakan untuk analisis statistik. Hasil penelitian ini Current Ratio tidak berpengaruh signifikan terhadap Debt to Equity Ratio, nilai Determinasi sebesar 21,5\%, uji hipotesis diperoleh $t_{\text {hitung }}<t_{\text {tabel }}$ atau $(-1,480<2,306)$. Return On Asset tidak berdampak signifikan terhadap Debt to Equity Ratio nilai Determinasi sebesar 13,9\%, uji hipotesis diperoleh $t_{\text {hitung }}<t_{\text {tabel }}$ atau $(-1,138<2,306)$. Current Ratio dan Return On Asset secara simultan tidak berpengaruh signifikan terhadap Debt to Equity Ratio diperoleh persamaan regresi $Y=36,963-0,409 X_{1}-24,424 X_{2}$ dan nilai determinasi sebesar 39,2\%, uji hipotesis diperoleh nilai $F_{\text {hitung }}<F_{\text {tabel }}$ atau $(2,259<4,350)$.
\end{abstract}

Kata Kunci : Current Ratio, Return on Asset, Debt to Equity Ratio

\begin{abstract}
This study aims to determine the effect of Current Ratio and Return On Assets on Debt to Equity Ratio at PT Duta Anggada Realty. The method used is explanatory research. The analysis technique with statistical analysis with regression testing, correlation, determination and hypothesis testing. The results of this study Current Ratio does not significantly influence the Debt to Equity Ratio, Determination value of 21.5\%, the hypothesis test obtained $t_{\text {count }}<t_{\text {table }}$ or $(-1,480<2,306)$. Return On Assets has no significant effect on Debt to Equity Ratio Determination value of $13.9 \%$, the hypothesis test obtained $t_{\text {count }}<t_{\text {table }}$ or $(-1,138<2,306)$. Current Ratio and Return On Assets simultaneously have no significant effect on Debt to Equity Ratio obtained by the regression equation $Y=36,963-0,409 X_{1}-24,424 X_{2}$ and the determination value of $39.2 \%$, the hypothesis test obtained the value of $F_{\text {count }}<F_{\text {table }}$ or $(2.259<4,350)$.
\end{abstract}

Keywords : Current Ratio, Return on Assets, Debt to Equity Ratio

\section{PENDAHULUAN}

Tujuan untuk meningkatkan kelancaran usahanya agar berjalan dengan baik dimiliki oleh setiap perusahaan. Pendanaan perusahaan meru- pakan hal penting dalam perusahaan sehingga mendapatkan keuntungan secara parsial (keseluruhan) merupakan keputusan perusahaan. Perusahaan properti yang berpengaruh pada 
pertumbuhan ekonomi di milenial sekarang karena tujuannya dalam investasi jangka panjang merupakan yakni indikator suatu perusahaan. Industri yang bergerak dibidang pengembangan jasa dengan memfasilitasi pembangunan kawasan-kawasan yang terpadu dan dinamis yaitu perusahaan properti dan real estate. Industri real estate and property dapat berupa landed property (perumahan, apartment, ruko, dan gedung perkantoran) dan commercial building (mall, plaza, atau trade canter) adalah produk yang dihasilkan.

Setiap keputusan mengenai pendanaan seimbang dengan modal cara perusahaan dalam mengolah modal secara baik dan perlu pertimbangan. Bagi perusahaan untuk mencapai tujuan yang maksimal modal adalah sumber utama. Karena properti merupakan aset yang cukup besar dan mampu dijadikan jaminan yang layak untuk meminjam uang di bank, dapat disewakan dan dapat dijual kembali dengan keuntungan yang lebih merupakan alasan mengenai investor lebih memilih menanamkan modalnya pada perusahaan properti. Cukup stabil terhadap inflasi yang terjadi pada suatu Negara, aset yang cocok untuk dimiliki. Kenaikan suatu harga secara terus-menerus disebabkan inflasi. Dianatara yang mendasari keputusan investor dalam melakukan investasi pada suatu perusahaan adalah dengan melihat laporan keuangan dari perusahaan. beberapa berita yang berkaitan dengan dinamika harga saham agar bisa mengambil keputusan tentang saham perusahaan yang layak untuk dipilih merupakan cara yang dilakukan investor. Pasar Modal adalah tempat untuk penilaian saham secara akurat bisa meminimalkan risiko sekaligus membantu investor mendapatkan keuntungan, mengingat investasi saham. Jenis investasi yang cukup berisiko tinggi meskipun menjanjikan keuntungan yang relatif besar adalah pasar modal.

Terbatasnya tanah dari tahun ke tahun cenderung mengalami kenaikan sedangkan jumlah permintaan semakin tinggi akibat dari naiknya jumlah penduduk contoh kendala perusahaan properti. Dengan demikian perusahaan properti terus meningkatkan jumlah kualitasnya mengingat persaingan global yang berkembang sangat pesat, sehingga apabila kualitas perusahaan me- nurun maka jumlah investor akan semakin berkurang.

Hal yang pokok bagi suatu perusahaan untuk dimanfaatkan sebagai suatu kebutuhan bagi operasionalnya, sumber-sumber yang biasanya banyak dikelola oleh manajer dalam meningkatkan kekayaan perusahaan untuk memperoleh laba yang maksimal adalah modal. Modal sendiri dari pemilik yang dijadikan sebagai modal perusahaan maupun modal asing terdiri dari hasil pinjaman perbankan, hasil penjualan saham, serta hutang dagang dan Obligasi yang diperoleh dari kegiatan pasar modal adalah definisi modal. Banyak elemen-elemen yang menghubungkan aktiva dengan passiva, dan apabila membandingkan elemenelemen tersebut suatu perusahaan pada saat tertentu adalah hutang dan profitabilitas suatu perusahaan pada saat tertentu (Riyanto, 2010).

Angsuran jangka panjang dan pembiayaan ekuitas adalah struktur modal (Brealey et al. 2012). Memiliki manfaat untuk mengurangi pajak dan keuntungan bagi pemegang saham karena tidak perlu membagi keuntungannya tetapi mempunyai kekurangan juga karena risiko penggunaan hutang semakin meningkat serta kebangkrutan saat perusahaan mengalami kerugian dan pendapatan tidak menutupi beban bunga adalah dasar penggunaan hutang. Maka bisa kita ketahui bahwa perusahaan harus menyesuaikan pendanaannya dengan baik sehingga risiko yang $\mathrm{n}$ dihadapi oleh perusahaan akan semakin kecil, dan kondisi perusahaan dapat seimbang.

Pendapat Brigham dan Houston (2011: 153) "jika perusahaan ingin tumbuh membutuhkan modal, dan modal tersebut dalam bentuk utang dan ekuitas". Teori trade-off dan teori pecking order merupakan teori penentuan struktur modal. menjelaskan bahwa perusahaan harus menyeimbangkan keuntungan dari pendanaan melalui hutang, yaitu tax shield dengan biaya hutang adalah Teori trade off (Ross, et al., 2010). Bahwa hutang memberikan keuntungan karena mengurangi pajak tex shield sedangkan teori yang mengedepankan pendanaan internal dibandingkan eksternal disebut pecking order adalah penjelasan dari teori ini.

Sangat berkembang pesat dalam pereko- 
nomian indonesia karena merupakan sandang pangan bagi masyarakat terutama tempat yang dibangun merupakan tempat yang strategis di industri bidang properti. Lahan (tanah), hunian (residensial), jenis bangunan perkantoran serta jenis bangunan untuk perdagangan (komersial) adalah jenis investasi secara umum dikategorikan dalam beberapa jenis Pada perusahaan real estate and properti (2013-2016) menemukan bahwa pengaruh asset size dan probability berpengaruh signifikan terhadap struktur modal sehingga perusahaan perlu meningkatkan nilai perusahaan menurut penelitian yang dilakukan oleh Eunike G.T., Sri M. dan Victoria N.U. (2019)

Proporsi dalam menentukan kebutuhan belanja perusahaan dimana dana yang diperoleh menggunakan kombinasi atau paduan sumber yang berasal dari dana jangka panjang yang terdiri dari dua sumber utama yakni yang berasal dari dalam dan luar perusahaan adalah struktur modal (Rodoni dan Ali, 2010:137). Dana yang didapatkan dari para pemegang saham, kreditur, dan pemilik perusahaan adalah sumber dana eksternal. Sedangkan berasal dari laba yang ditahan adalah sumber dana internal. Untuk dana yang berasal dari para kreditur akan menjadi hutang bagi perusahaan adalah sumber dana internal. Pemegang saham menjadi peran penting dalam mengambil keputusan pendanaan untuk menentukan proporsi hutang merupakan fund dari pemilik modal sendiri.

Bagaimana manajemen tersebut dapat mengendalikannya adalah faktor yang dapat mempengaruhi struktur modal. Dalam penelitian ini, peneliti hanya membatasi beberapa faktor yang diteliti yang diduga berpengaruh terhadap struktur modal diantaranya likuiditas dan profitabilitas ada banyak faktor-faktor yang dapat mempengaruhi komposisi struktur modal perusahaan.

Kemampuan perusahaan dalam melunasi hutang jangka pendeknya adalah likuiditas. Jika tingkat likuiditas suatu perusahaan tinggi, maka perusahaan itu tidak akan menggunakan pembiayaan dari hutang karena tersedianya dana internal yang mencukupi untuk membiayai aktivitas perusahaan. Di Kroasia yang menemukan bahwa likuiditas berpengaruh negatif dan signifikan terhadap hutang berdasarkan penelitian dari Sarlija dan Harc (2012). Bagi berbagai pihak yang berkepentingan terhadap perusahaan merupakan manfaat dari likuiditas. Untuk menilai perusahaan dalam membayar kewajibannya yang dilakukan oleh pemilik perusahaan dan manajemen perusahaan. Alat-alat likuid yang berupa aktiva lancar yang harus lebih besar dari pada jumlah kewajiban yang berupa hutang lancer bagian dari perusahaan .

Maka semakin tinggi tingkat likuiditas perusahaan tersebut jika semakin banyak jumlah aktiva lancar yang dimiliki oleh perusahaan dibanding dengan hutang lancar. Pinjaman lancar maka perusahaan tersebut berada dalam likuid dikatakan likuid apabila jumlah aktiva lancar lebih sedikit. Karena likuiditas menunjukkan ketersediaan modal kerja yang di butuhkan dalam aktivitas operasional. Tingkat likuiditas berpengaruh pada struktur modal, jadi apabila perusahaan mengeluarkan modal harus bisa seimbang tidak bisa berlebihan dan juga kekurangan adalah laba bersih belum sepenuhnya stabil atau naik turun pertahun.

Menunjukkan besarnya kemampuan perusahaan dalam menghasilkan laba adalah profitabilitas. Cenderung mempunyai tingkat hutang yang rendah karena kegiatan operasionalnya dapat didanai dari laba ditahan yang tinggi adalah perusahaan dengan tingkat profitabilitas yang tinggi. Mengenai profitabilitas sangat penting bagi kreditor dan investor ekuitas adalah analisis. Menggunakan Return on Asset (ROA) karena dapat memberikan gambaran tingkat pengembalian keuntungan yang diperoleh investor atas investasinya adalah Rasio yang digunakan (Prasinta, 2012). "Return on Asset (ROA) dipakai untuk mengukur kinerja company" (Tulung dan Ramdani. 2016). Perusahaan dengan profitabilitas tinggi tentu memiliki dana internal yang lebih banyak daripada perusahaan dengan profitabilitas rendah.

PT Duta Anggada Realty Tbk adalah perusahaan terutama bergerak dalam bidang pembangunan real estate dengan ruang lingkup kegiatan perusahaan adalah pembangunan apar- 
temen, penjualan, penyewaan dan pengelolaan bangunan apartemen, perkantoran, pusat perbelanjaan, pariwisata perhotelan, dan kegiatan usaha lain yang berhubungan. Tercatat di Bursa Efek Indonesia (BEI) sejak tahun 1990, dan aktivitasnya kurang lebih 34 tahun adalah PT. Duta Anggada Realty, Tbk Kantor Pusat Perusahaan Beralokasi Di Gedung Chase Plaza Jalan Jendral Sudirman Kav. 21, Jakarta.

\begin{tabular}{|c|c|c|c|c|}
\hline \multicolumn{5}{|c|}{$\begin{array}{c}\text { Tabel 1. Pengaruh Likuiditas Current Ratio (CR) } \\
\text { dan Profitabilitas Return on Asset (ROA) } \\
\text { Terhadap Struktur Modal Debt to Equity Ratio (DER) pada } \\
\text { PT. Duta Anggada Realty, Tbk tahun 2008-2017 (dalam persen) }\end{array}$} \\
\hline No & Tahun & $\begin{array}{c}\text { Current Ratio } \\
\qquad \%]\end{array}$ & $\begin{array}{c}\text { Return On Asset } \\
(\%)\end{array}$ & $\begin{array}{c}\text { Debt to Equity } \\
\text { Ratio }(\%)\end{array}$ \\
\hline 1 & 2008 & 4,21 & 3.63 & 434.52 \\
\hline 2 & 2009 & 3,42 & 0.94 & 482.75 \\
\hline 3 & 2010 & 59,21 & 1.05 & 346.67 \\
\hline 4 & 2011 & 66,68 & 1.55 & 182.93 \\
\hline 5 & 2012 & 116,37 & 4.21 & 157.52 \\
\hline 6 & 2013 & 201,50 & 3.79 & 162.93 \\
\hline 7 & 2014 & 187,25 & 7.98 & 157.52 \\
\hline 8 & 2015 & 66,41 & 3.10 & 167.42 \\
\hline 9 & 2016 & 64,43 & 3.16 & 167.42 \\
\hline 10 & 2017 & 536,46 & 0.47 & 178.70 \\
\hline \multicolumn{5}{|c|}{ Sumber: PT. Duta Anggada Realty } \\
\hline
\end{tabular}

Berdasarkan informasi pada data tabel di atas menunjukkan bahwa kondisi Current Ratio, Return on Asset, dan Debt to Equity Ratio mengalami perkembangan yang fluktuatif. Current Ratio terendah terjadi pada tahun 2008 dan 2016 dimana hanya mampu mencapai 3,42\%, sedangkan Current Ratio tertinggi berhasil dicapai pada tahun 2012 mencapai 201,5\%. Return on Asset terendah terjadi pada tahun 2015 dimana hanya mampu mencapai $0,47 \%$, sedangkan Return On Asset tertinggi berhasil dicapai pada tahun 2012 mencapai 7,98\%. Debt to Equity Ratio terendah terjadi pada tahun 2010 dimana hanya mampu mencapai 151,29\%, sedangkan Debt to Equity Ratio tertinggi berhasil dicapai pada tahun 2008 dan 2016 mencapai 346,67\%.

\section{METODE}

\section{Populasi}

Populasi dalam penelitian ini berdasar laporan keuangan selama 10 tahun PT Duta Anggada Realty.

\section{Sampel}

Sampel jenuh adalah teknik pengambilan sampling dalam penelitian, dimana semua anggota populasi dijadikan sebagai sampel. Dengan demikian sampel dalam penelitian ini laporan keuangan selama 10 tahun.

\section{Jenis Penelitian}

Asosiatif jenis penelitian yang digunakan, dimana tujuannya adalah untuk mengetahui mencari keterhubungan antar variabel independen terhadap variabel dependen

\section{Metode Analisis Data}

Uji asumsi klasik, regresi, koefisien korelasi, koefisien determinasi dan uji hipotesis baik parsial maupun simultan adalah metode Analisis data yang dipakai.

\section{HASIL dan PEMBAHASAN Current Ratio}

Aset lancar dengan current liabilities adalah rasio likuiditas. "Jika perusahaan tingkat likuiditasnya baik maka tingkat resiko pengembalian hutang jangka pendek jumlah tinggi, dan dapat terhindar dari masalah likuiditas". (Mardinawati, 2011)" menyatakan perusahaan yang mempunyai likuiditas tinggi berarti mempunyai kemampuan membayar hutang jangka pendek, sehingga cenderung akan menurunkan total hutang, yang akhirnya struktur modal akan menjadi lebih kecil'. Hal ini yang dapat menarik investor untuk menanamkan modalnya pada perusahaan.

\section{Return On Equity}

Rasio profitabilitas Return on Equity (ROE) merupakan rasio yang menggambarkan tingkat keuntungan laba yang diperoleh perusahaan kepada para pemegang saham biasa dengan tujuan untuk menarik para pemegang saham yang dananya telah digunakan perusahaan. (Arta, 2013) menyatakan berarti laba bersih yang diperoleh semakin besar. Pembayaran dividen kepada para pemegang saham tentu semakin bertambah besar sehingga terjadi kenaikan pengembalian saham bahwa semakin tinggi Return on Equity (REO). 
Tujuannya memperoleh laba atau keuntungan dari hasil investor menanamkan modalnya pada perusahaan yang bersangkutan hal ini yang sering menjadi pertimbangan bagi investor atau pemegang saham.

Tingkat profitabilitas yang rendah biasanya di sebabkan oleh penggunaan hutang yang terlalu berlebihan, oleh sebab itu para pemegang saham akan memberikan pertimbangan sebelum menanamkan modalnya pada perusahaan, yang dapat di hitung dengan rasio profitabilitas. Tingkat keuntungan bersih yang mampu diraih perusahaan pada saat menjalankan operasinya adalah profitabilitas (Mahendra et al, 2012).

\section{Debt to Equity Ratio}

Perbandingan atau imbangan pendanaan jangka panjang perusahaan yang ditunjukkan oleh perbandingan hutang jangka panjang terhadap modal sendiri adalah struktur modal (Martono dan Harjito, 2010: 240). Peranan penting bagi perusahaan karena berpengaruh langsung terhadap posisi laporan keuangan, salah satu dampak yang mempengaruhi struktur modal disebabkan oleh nilai suatu perusahaan merupakan struktur modal. Kesalahan dalam mengelola struktur modal akan mengakibatkan utang yang besar, dan ini juga akan meningkatkan resiko keuangan karena ketidaksanggupan perusahaan dalam membayar beban (A.A Ngr Ag Ditya, Yudi P. dan Made R. Dewi 2016). Bahwa tingkat likuiditas berpengaruh positif dan signifikan terhadap struktur modal berbeda dengan profitabilitas yang berpengaruh negatif dan tidak signifikan terhadap struktur modal, dimana tingkat profitabilitas yang tinggi cenderung menggunakan hutang yang kecil, sehingga memungkinkan perusahaan untuk menggunakan dana internal. Penjelasan struktur modal diatas peneliti menggunakan rasio Debt to Equity Ratio (DER). Menurut (Sugiyono. 59: 2012). Struktur modal yang diukur dengan Debt to Equity Ratio (DER) adalah variabel dependen dalam penelitian ini .

\section{Hasil}

\section{Uji Asumsi Klasik}

Untuk mengetahui ketepatan sebuah data adalah uji asumsi klasik. (Singgih Santoso, 2011) "Sebuah model regresi akan digunakan untuk melakukan peramalan, sebuah model yang baik adalah model dengan kesalahan peramalan yang seminimal mungkin". Sebuah model sebelum digunakan seharusnya memenuhi beberapa asumsi, yang biasa disebut asumsi klasik. Asumsi klasik yang digunakan adalah meliputi: Uji Normalitas, Uji Multikolinearitas, Uji Autokorelasi, dan Uji Heterokedastisitas adalah penelitian yang diuji. Adapun hasilnya sebagai berikut:

\section{a. Uji Normalitas}

Untuk menguji apakah dalam model regresi, variabel dependen dan variabel independen berdistribusi normal atau berdistribusi tidak normal adalah uji normalitas. Dalam penelitian ini uji normalitas dilakukan dengan melihat grafik probability plot. Adapun hasil pengujian sebaga berkut:

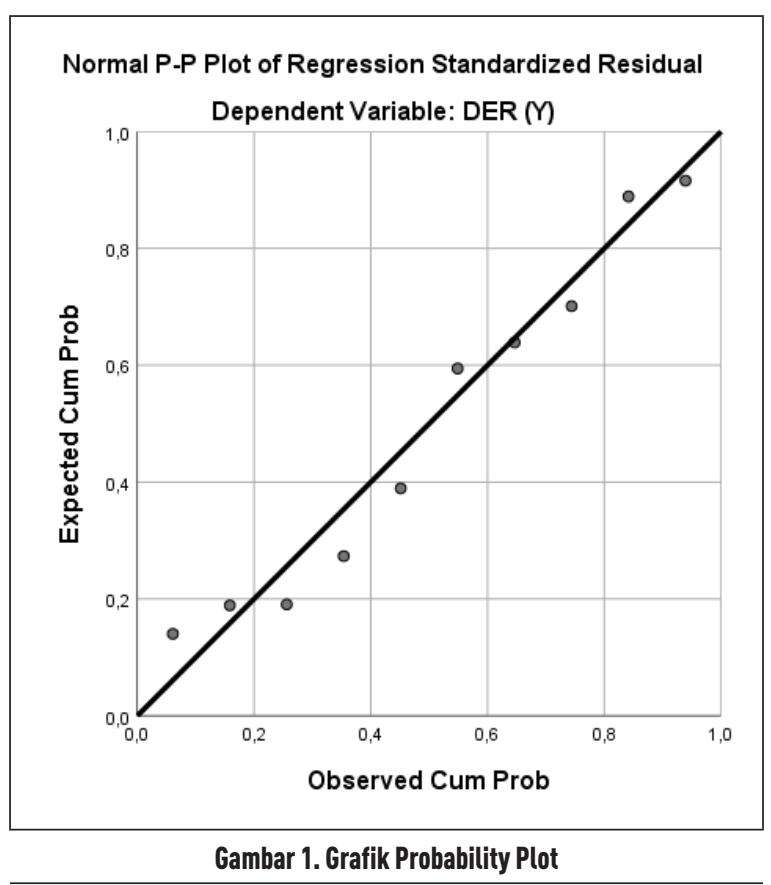

Pada gambar diatas adalah hasil pengujian, menunjukkan titik-titik mengikuti arah garis diagonal. Maka asumsi distribusi persamaan pada uji ini adalah normal.

\section{b. Uji Multikonilieritas}

Dilakukan untuk meyakini bahwa antar variabel bebas tidak memiliki multikolinearitas atau tidak memiliki pengaruh korelasi antara variabel yang ditetapkan se- 
bagai model dalam penelitian merupakan pengujian multikolinearitas. Dengan melihat nilai Tolerance Value dan Variance Inflation Factor (VIF) merupakan uji multikolinearitas. Adapun hasil pengujiannya sebagai berikut:

\begin{tabular}{|c|c|c|c|c|c|c|c|c|}
\hline \multicolumn{9}{|c|}{$\begin{array}{l}\text { Tabel 2. Hasil Uji Multikolinieritas deng } \\
\text { Coefficients }^{\mathrm{a}}\end{array}$} \\
\hline \multirow{2}{*}{\multicolumn{2}{|c|}{ Model }} & \multicolumn{2}{|c|}{$\begin{array}{l}\text { Unstandardized } \\
\text { Coefficients }\end{array}$} & \multirow{2}{*}{$\begin{array}{c}\begin{array}{c}\text { Standard- } \\
\text { ized Coef- } \\
\text { ficients }\end{array} \\
\text { Beta }\end{array}$} & \multirow{2}{*}{$t$} & \multirow{2}{*}{ Sig. } & \multicolumn{2}{|c|}{$\begin{array}{l}\text { Collinearity } \\
\text { Statistics }\end{array}$} \\
\hline & & B & $\begin{array}{l}\text { Std. } \\
\text { Error }\end{array}$ & & & & $\begin{array}{l}\text { Toler- } \\
\text { ance }\end{array}$ & VIF \\
\hline \multirow{3}{*}{1} & (Constant) & 36963 & 7193,316 & & 5,139 & ,001 & & \\
\hline & $C R\left(X_{1}\right)$ & -409 &, 240 & -505 & $-1,707$ &, 132 & .990 & 1,010 \\
\hline & $\operatorname{ROA}\left(\mathrm{X}_{2}\right)$ & $-24,424$ & 17,094 &,- 423 & $-1,429$ & , 196 & .990 & 1,010 \\
\hline
\end{tabular}

Hasil pengujian pada tabel diatas nilai tolerance masing-masing variabel bebas yaitu $0,990<1,0$ dan nilai Variance Inflation Factor (VIF) sebesar 1,010 < 10, dengan demikian model regresi ini tidak terjadi multikolinearitas.

\section{c. Uji Heteroskesdastisitas}

Untuk menguji apakah dalam sebuah model regresi terjadi ketidaksamaan varians residual dilakukan pengujian heteroskedastisitas. Hasil pengujiannya sebagai berikut:

\begin{tabular}{|c|c|c|c|c|c|c|}
\hline \multicolumn{7}{|c|}{ Tabel 3. Hasil Uji Heteroskesdastisitas dengan Glejser Test Model } \\
\hline \multirow{2}{*}{\multicolumn{2}{|c|}{ Model }} & \multicolumn{2}{|c|}{$\begin{array}{l}\text { Unstandardized } \\
\text { Coefficients }\end{array}$} & \multirow{2}{*}{$\begin{array}{c}\begin{array}{c}\text { Standardized } \\
\text { Coefficients }\end{array} \\
\text { Beta }\end{array}$} & \multirow{2}{*}{$t$} & \multirow{2}{*}{ Sig. } \\
\hline & & B & $\begin{array}{l}\text { Std. } \\
\text { Error }\end{array}$ & & & \\
\hline \multirow{3}{*}{1} & (Constant) & 11605 & 2582,229 & & 4,494 & ,003 \\
\hline & $C R\left(X_{1}\right)$ &,- 178 & 086 &,- 617 & $-2,069$ & .077 \\
\hline & $\mathrm{ROA}\left(\mathrm{X}_{2}\right)$ & $-3,001$ & 6,136 &,- 146 &,- 489 & ,640 \\
\hline
\end{tabular}

Hasil pengujian dengan menggunakan uji glejser diperoleh nilai Sig. $>0,05$. Regresi model tidak ada gangguan heteroskesdastisitas. Ini adalah hasilnya.

\section{Analisis Deskriptif}

Pada pengujian ini digunakan untuk mengetahui besarnya persentase minimum dan maksimum, persentase rata-rata dan standar deviasi dari masing-masing variabel. Adapun hasilnya sebagai berikut:

\begin{tabular}{|l|c|r|r|r|r|}
\hline \multicolumn{7}{|c|}{ Tabel 4. Hasil Analisis Descriptive Statistics } \\
\hline & N & Minimum & Maximum & Mean & $\begin{array}{c}\text { Std. } \\
\text { Deviation }\end{array}$ \\
\hline CR $\left(X_{1}\right)$ & 10 & 342 & 53646 & 13059 & 15740,647 \\
\hline ROA $\left(X_{2}\right)$ & 10 & 47 & 798 & 298 & 220,779 \\
\hline DER (Y) & 10 & 15129 & 48275 & 24321 & 12745,514 \\
\hline Valid N (listwise) & 10 & & & & \\
\hline
\end{tabular}

Current Ratio diperoleh nilai minimum sebesar $34,2 \%$ dan nilai maximum $53,60 \%$ dengan rata-rata sebesar $13,1 \%$ dengan standar deviasi 15,7\%. Return On Asset diperoleh nilai minimum sebesar $47 \%$ dan nilai maximum 79,8\% dengan nilai rata-rata sebesar29,8\% dengan standar deviasi $22 \%$. Debt to Equity Ratio diperoleh nilai minimum sebesar $15,1 \%$ dan nilai maximum $48,2 \%$ dengan rata-rata sebesar $24,3 \%$ dengan standar deviasi $12,7 \%$.

\section{Analisis Verifikatif}

Untuk mengetahui pengaruh variabel independen terhadap variabel dependen adalah analisis verifikatif. Adapun hasil pengujian sebagai berikut:

\section{a. Analisis Regresi}

Untuk mengetahui perubahan variabel dependen jika variabel independen mengalami perubahan adalah uji regresi. Adapun hasil pengujiannya sebagai berikut:

Tabel 5. Hasil Pengujian Regresi Liner Sederhana CR ( $X_{1}$ ) terhadap DER (Y)

\begin{tabular}{|c|c|c|c|c|c|c|}
\hline \multicolumn{7}{|c|}{ Coefficients $\mathrm{a}^{\mathrm{a}}$} \\
\hline \multirow{2}{*}{\multicolumn{2}{|c|}{ Model }} & \multicolumn{2}{|c|}{$\begin{array}{l}\text { Unstandardized } \\
\text { Coefficients }\end{array}$} & \multirow{2}{*}{$\begin{array}{c}\begin{array}{c}\text { Standardized } \\
\text { Coefficients }\end{array} \\
\text { Beta }\end{array}$} & \multirow{2}{*}{$t$} & \multirow{2}{*}{ Sig. } \\
\hline & & B & $\begin{array}{l}\text { Std. } \\
\text { Error }\end{array}$ & & & \\
\hline \multirow{2}{*}{1} & (Constant) & 29,224 & 5031 & & 5,808 & ,000 \\
\hline & $C R\left(X_{1}\right)$ &,- 375 & ,254 &,- 464 & $-1,480$ & , 177 \\
\hline & bendent & Q (Y) & & & & \\
\hline
\end{tabular}

Berdasarkan hasil pengujoan pada tabel di atas, diperoleh persamaan regresi $\mathrm{Y}=$ 29,224 - 0,375X . Dari persamaan tersebut dijelaskan sebagai berikut:

1) Konstinta sebesar 29,224 diartikan jika Current Ratio dan Return on Asset tidak ada, maka telah terdapat nilai Debt to Equity Ratio sebesar 29,224 point.

2) Koefisiien regresi Current Ratio sebesar 
$-0,375$, angka ini negatif artinya setiap ada penurunan Current Ratio sebesar -0,375 maka Debt to Equity Ratio juga akan mengalami penurunan sebesar $-0,375$ point.

\begin{tabular}{|c|c|c|c|c|c|c|}
\hline \multicolumn{7}{|c|}{ Coefficients $^{\mathrm{a}}$} \\
\hline \multirow{2}{*}{\multicolumn{2}{|c|}{ Model }} & \multicolumn{2}{|c|}{$\begin{array}{l}\text { Unstandardized } \\
\text { Coefficients }\end{array}$} & \multirow{2}{*}{$\begin{array}{c}\begin{array}{c}\text { Standardized } \\
\text { Coefficients }\end{array} \\
\text { Beta }\end{array}$} & \multirow{2}{*}{$t$} & \multirow{2}{*}{ Sig. } \\
\hline & & B & $\begin{array}{l}\text { Std. } \\
\text { Error }\end{array}$ & & & \\
\hline \multirow{2}{*}{1} & (Constant) & 30,759 & 6909 & & 4,452 & ,002 \\
\hline & $\operatorname{ROA}\left(X_{2}\right)$ & $-21,545$ & 18,936 &,- 373 & $-1,138$ & 288 \\
\hline \multicolumn{7}{|c|}{$R(Y)$} \\
\hline
\end{tabular}

Berdasarkan hasil pengujian pada tabel di atas, diperoleh persamaan regresi $\mathrm{Y}=$ $30,759-21,545 \mathrm{X}_{2}$. Dari persamaan tersebut dijelaskan sebagai berikut:

1) Konstaanta sebesar 30,759 diartikan jika Current Ratio dan Return On Asset tidak ada, maka telah terdapat nilai Debt to Equity Ratio sebesar 30,759 point.

2) Koefiisien regresi Current Ratio sebesar -21,545, angka ini negatif artinya setiap ada penurunan Current Ratio sebesar -21,545 maka Debt to Equity Ratio juga akan mengalami penurunan sebesar $-21,545$ point.

\begin{tabular}{|c|c|c|c|c|c|c|}
\hline \multicolumn{7}{|c|}{$\begin{array}{l}\text { Tabel 7. Hasil Pengujian Regresi Liner Ber } \\
\text { Coefficients }\end{array}$} \\
\hline \multirow{2}{*}{\multicolumn{2}{|c|}{ Model }} & \multicolumn{2}{|c|}{$\begin{array}{l}\text { Unstandardized } \\
\text { Coefficients }\end{array}$} & \multirow{2}{*}{$\begin{array}{c}\begin{array}{c}\text { Standardized } \\
\text { Coefficients }\end{array} \\
\text { Beta }\end{array}$} & \multirow{2}{*}{$t$} & \multirow{2}{*}{ Sig. } \\
\hline & & B & $\begin{array}{c}\text { Std. } \\
\text { Error }\end{array}$ & & & \\
\hline \multirow{3}{*}{1} & (Constant) & 36,963 & 7193 & & 5,139 &, 001 \\
\hline & $C R\left(X_{1}\right)$ & -.409 & ,240 &,- 505 & $-1,707$ & 132 \\
\hline & $\operatorname{ROA}\left(X_{2}\right)$ & $-24,424$ & 17,094 &,- 423 & $-1,429$ & , 196 \\
\hline
\end{tabular}

Berdasarkan hasil pengujian pada tabel di atas, diperoleh persamaan regresi $\mathrm{Y}=$ $36,963-0,409 \mathrm{X}_{1}-24,424 \mathrm{X}_{2}$. Dari persamaan tersebut dijelaskan sebagai berikut:

1) Konstannta sebesar 36,963 diartikan jika Current Ratio dan Return On Asset tidak ada, maka telah terdapat nilai Debt to Equity Ratio sebesar 36,963 point.

2) Koefisieen regresi Current Ratio sebesar
$-0,409$, angka ini negatif artinya setiap ada penurunan Current Ratio sebesar -0,409 maka Debt to Equity Ratio juga akan mengalami penurunan sebesar $-0,409$ point.

3) Koefisiien regresi Return On Asset sebesar -24,424, angka ini negatif artinya setiap ada penurunan Return On Asset sebesar -24,424 maka Debt to Equity Ratio juga akan mengalami penurunan sebesar $-24,424$ point.

\section{b. Analisis Koefisien Korelasi}

Analisiss koefisien korelasi dimaksudkan untuk mengetahui tingkat kekuatan hubungan dari variabel independen terhadap variabel dependen baik secara parsiial maupun simultan. Adapun hasil pengujian sebagai berikut:

\begin{tabular}{|c|c|c|c|}
\hline \multicolumn{4}{|c|}{$\begin{array}{l}\text { Tabel 8. Hasil Pengujian Koefisien Korelasi } \\
\text { Current Ratio Terhadap Debt to Equity Ratio }\end{array}$} \\
\hline \multicolumn{4}{|c|}{ Coefficients $^{\mathrm{a}}$} \\
\hline & & $C R\left(X_{1}\right)$ & $\operatorname{DER}(Y)$ \\
\hline \multirow{2}{*}{$\operatorname{CR}\left(X_{1}\right)$} & Pearson Correlation & 1 &,- 464 \\
\hline & Sig. (2-tailed) & & .177 \\
\hline \multirow{2}{*}{$\operatorname{DER}(Y)$} & Pearson Correlation & -.464 & 1 \\
\hline & Sig. (2-tailed) & 177 & \\
\hline a. Listwi & & & \\
\hline
\end{tabular}

Berdasarkan hasil pengujian diperoleh nilai koorelasi sebesar -0,464 artinya Current Ratio memiliki hubungan yang negatif sedang terhadap Debt to Equity Ratio.

\begin{tabular}{|c|c|c|c|}
\hline \multicolumn{4}{|c|}{$\begin{array}{l}\text { Tabel 9. Hasil Pengujian Koefisien Korelasi } \\
\text { Return On Asset Terhadap Debt to Equity Ratio }\end{array}$} \\
\hline \multicolumn{4}{|c|}{ Coefficients ${ }^{\mathrm{a}}$} \\
\hline & & $\operatorname{ROA}\left(\mathrm{X}_{2}\right)$ & $\operatorname{DER}(Y)$ \\
\hline \multirow{2}{*}{$\mathrm{ROA}\left(\mathrm{X}_{2}\right)$} & Pearson Correlation & 1 &,- 373 \\
\hline & Sig. (2-tailed) & & ,288 \\
\hline \multirow{2}{*}{ DER (Y) } & Pearson Correlation &,- 373 & 1 \\
\hline & Sig. (2-tailed) & ,288 & \\
\hline
\end{tabular}

Berdasarkan hasil pengujian diperoleh nilai korelasi sebesar -0,373 artinya Return On Asset memiliki hubungaan yang negatif rendah terhadap Debt to Equity Ratio. 


\begin{tabular}{l} 
Tabel 10. Hasil Pengujian Koefisien Korelasi Current Ratio dan \\
Return On Asset secara simultan Terhadap Debt to Equity Ratio \\
\begin{tabular}{|c|c|c|c|c|}
\hline \multicolumn{5}{|c|}{ Model Summary } \\
\hline Model & R & R Square & $\begin{array}{c}\text { Adjusted R } \\
\text { Square }\end{array}$ & $\begin{array}{c}\text { Std. Error of the } \\
\text { Estimate }\end{array}$ \\
\hline 1 &,$- 626^{\mathrm{a}}$ &, 392 &, 219 & 11266,818 \\
\hline
\end{tabular} \\
\hline
\end{tabular}

Berdasarkan hasiil pengujian diperoleh nilai korelasi sebesar -0,626 artinya Current Ratio dan Return On Asset secara simultan memiliki hubungan yang negatif kuat terhadap Debt to Equity Ratio.

c. Analisis Koefisien Determinasi

Analisis koefisien determinasi dimaksudkan untuk mengetahui besarnya persentase pengaruh dari variabel independen terhadap variiabel dependen baik secara parsial maupun simultan. Adapun hasil pengujian sebagai berikut:

\begin{tabular}{l} 
Tabel 11. Hasil Pengujian Koefisien \\
Determinasi Current Ratio Terhadap Debt to Equity Ratio \\
\begin{tabular}{|c|c|c|c|c|}
\hline Model Summary \\
\hline Model & R & R Square & $\begin{array}{c}\text { Adjusted R } \\
\text { Square }\end{array}$ & $\begin{array}{c}\text { Std. Error of the } \\
\text { Estimate }\end{array}$ \\
\hline 1 &, $464^{\mathrm{a}}$ &, 215 &, 117 & 11977,754 \\
\hline
\end{tabular} \\
a. Predictors: (Constant), CR (X) \\
\hline
\end{tabular}

Berdasarkan hasil pengujiian diperoleh nilai determinasi sebesar 0,215 artinya Current Ratio memiliki kontribusi pengaruh sebesar 21,5\% terhadap Debt to Equity Ratio.

\begin{tabular}{|c|c|c|c|c|}
\hline \multicolumn{5}{|c|}{$\begin{array}{l}\text { Tabel 12. Hasil Pengujian Koefisien Determinasi } \\
\text { Return On Asset Terhadap Debt to Equity Ratio }\end{array}$} \\
\hline \multicolumn{5}{|c|}{ Model Summary } \\
\hline Model & $\mathbf{R}$ & R Square & $\begin{array}{l}\text { Adjusted R } \\
\text { Square }\end{array}$ & $\begin{array}{l}\text { Std. Error of the } \\
\text { Estimate }\end{array}$ \\
\hline 1 & $.373^{a}$ & .139 &, 032 & 12541,959 \\
\hline a. Predic & . & eturn On & $\left(X_{2}\right)$ & \\
\hline
\end{tabular}

Berdasarkan hasil pengujian diperoleh nilai determinasi sebesar 0,139 artinya Return On Asset memiliki kontribusi pengaruh sebesar 13,9\% terhadap Debt to Equity Ratio.

Tabel 13. Hasil Pengujian Koefisien Determinasi Current Ratio dan Return On Asset Terhadap Debt to Equity Ratio

\begin{tabular}{|c|c|c|c|c|}
\hline \multicolumn{5}{|c|}{ Model Summary } \\
\hline Model & $\mathbf{R}$ & R Square & $\begin{array}{c}\text { Adjusted R } \\
\text { Square }\end{array}$ & $\begin{array}{l}\text { Std. Error of the } \\
\text { Estimate }\end{array}$ \\
\hline 1 &, $626^{\mathrm{a}}$ & .392 & ,219 & 11266,818 \\
\hline \multicolumn{5}{|c|}{ a. Predictors: (Constant), Return On Asset $\left(X_{2}\right)$, Current Ratio $\left(X_{1}\right)$} \\
\hline
\end{tabular}

Berdasarkan hasil pengujian diperoleh nilai determinasi sebesar 0,392 artinya Current Ratio dan Return On Asseet secara simultan memiliki kontribusi pengaruh sebesar 39,2\% terhadap Debt to Equity Ratio, sedangkan sisanya sebesar $60,8 \%$ dipengaruhi faktor lain.

\section{d. Uji Hipotesis}

\section{Uji hipotesis Parsial (Uji t)}

Pengujian hipotesiis dengan uji $t$ digunakan untuk mengetahui hipotesis parsial mana yang diterima.

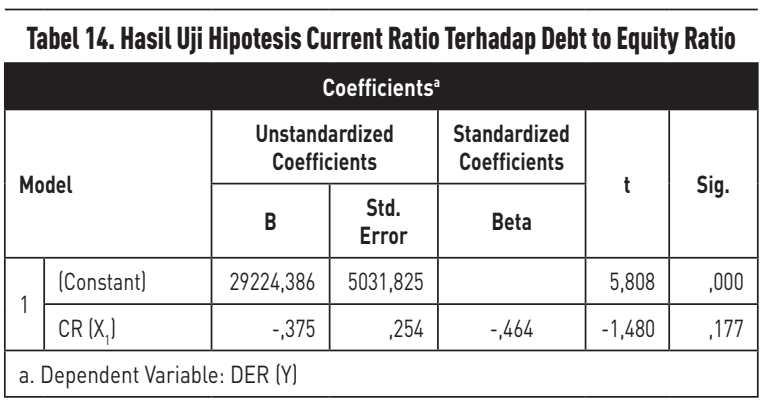

Berdasarkan hasil pengujian pada tabel di atas, diperoleh nilai $\mathrm{t}_{\text {hitung }}<\mathrm{t}_{\text {tabel }}$ atau (-1,480 $<2,306$ ), dengan demikian tidak terdapat pengaruh yang signifikan antara Current Ratio terhadap Debt to Equity Ratio.

\begin{tabular}{|c|c|c|c|c|c|c|}
\hline \multicolumn{7}{|c|}{$\begin{array}{l}\text { Tabel 15. Hasil Uji Hipotesis Return On Asset } 1 \\
\text { Coefficients }\end{array}$} \\
\hline \multirow{2}{*}{\multicolumn{2}{|c|}{ Model }} & \multicolumn{2}{|c|}{$\begin{array}{l}\text { Unstandardized } \\
\text { Coefficients }\end{array}$} & \multirow{2}{*}{$\begin{array}{c}\begin{array}{c}\text { Standardized } \\
\text { Coefficients }\end{array} \\
\text { Beta }\end{array}$} & \multirow{2}{*}{$t$} & \multirow{2}{*}{ Sig. } \\
\hline & & B & $\begin{array}{l}\text { Std. } \\
\text { Error }\end{array}$ & & & \\
\hline \multirow{2}{*}{1} & (Constant) & 30759,024 & 6909,669 & & 4,452 & .002 \\
\hline & $\operatorname{ROA}\left(X_{2}\right)$ & $-21,545$ & 18,936 &,- 373 & $-1,138$ & ,288 \\
\hline
\end{tabular}

Berdasarkan hasil pengujian pada tabel di atas, diperoleh nilai $\mathrm{t}_{\text {hitung }}<\mathrm{t}_{\text {tabel }}$ atau (-1,138 $<2,306)$, dengan demikian tidak terdapat pengaruh yang signifikan antara Return On Asset terhadap Debt to Equity Ratio.

\section{Uji Hipotesis Simultan (Uji F)}

Digunakan untuk mengetahui hipotesis simultan yang mana yang diterima adalah pengujian hipotesis dengan uji $\mathrm{F}$. 


\begin{tabular}{|c|c|c|c|c|c|c|}
\hline \multicolumn{7}{|c|}{$\begin{array}{l}\text { Tabel 16. Hasil Uji Hipotesis Current Ratio dan Return On Asset } \\
\text { Terhadap Debt to Equity Ratio }\end{array}$} \\
\hline & \multicolumn{6}{|c|}{ ANOVA $^{a}$} \\
\hline \multicolumn{2}{|c|}{ Model } & $\begin{array}{l}\text { Sum of } \\
\text { Squares }\end{array}$ & Df & $\begin{array}{l}\text { Mean } \\
\text { Square }\end{array}$ & $\mathrm{F}$ & Sig. \\
\hline \multirow{3}{*}{1} & Regression & 573444769 & 2 & 286722384 & 2,259 & ,175" \\
\hline & Residual & 888588297 & 7 & 126941185 & & \\
\hline & Total & 1462033066 & 9 & & & \\
\hline
\end{tabular}

Berdasarkan hasiil pengujian pada tabel di atas, diperoleh nilai $\mathrm{F}_{\text {hitung }}<\mathrm{F}_{\text {tabel }}$ atau $(2,259$ $<4,350$ ), dengan demikian tidak terdapat pengaruh antara Current Ratio dan Return On Asset terhadap Debt to Equity Ratio.

\section{Pembahasan}

\section{Pengaruh Current Ratio}

\section{Terhadap Debt to Equity Ratio}

Current Ratio tidak berpengaruh signiifikan terhadap Debt to Equity Ratio dengan korelasi sebesar -0,464 atau memiliki hubungan yang negatif sedang dengan kontribusi pengaruh sebesar $21,5 \%$. Pengujian hipotesis diperoleh nilai $t_{\text {hitung }}$ $<\mathrm{t}_{\text {tabel }}$ atau $(-1,4809<2,306)$. Dengan demikian tidak terdapat pengaruh antara Current Ratio terhadap Debt to Equity Ratio.

\section{Pengaruh Return On Asset}

\section{Terhadap Debt to Equity Ratio}

Return On Asset tidak berpengaruh signifikan terhadap Debt to Equity Ratio dengan korelasi sebesar -0,373 atau memiliki hubungaan yang negatif rendah dengan kontribusi pengaruh sebesar 13,9\%. Pengujian hipotesis diperoleh nilai $\mathrm{t}_{\text {hitung }}<\mathrm{t}_{\text {tabel }}$ atau $(-1,138<2,306)$. Dengan demikian terdapat tidak pengaruh antara Return On Asset terhadap Debt to Equity Ratio.

\section{Pengaruh Current Ratio dan}

\section{Return On Asset Terhadap Debt to Equity Ratio}

Current Ratio dan Return On Asset tiidak berpengaruh signifikan terhadap Debt to Equity Ratio dengan diperoleh persamaan regresi $\mathrm{Y}$ $=36,963-0,409 \mathrm{X}_{1}-24,424 \mathrm{X}_{2}$, nilai korelasi sebesar -0,626 atau memiliki hubungan yang kuat deengan kontribusi pengaruh sebesar 39,2\% sedangkan sisanya sebesar $60,8 \%$ dipengaruhi faktor lain. Pengujian hipotesis diperoleh nilai $\mathrm{F}_{\text {hitung }}$
$<\mathrm{F}_{\text {tabel }}$ atau $(2,259<4,350)$. Dengan demikian tidak terdapat pengaruh antara Current Ratio dan Return On Asset terhadap Debt to Equity Ratio.

\section{SIMPULAN}

Current Ratio tidak berpengaruh signifikan terhadap Debt to Equity Ratio dengan kontribusi pengaruh sebesar 21,5\%. Uji hipotesis diperoleh nilai $\mathrm{t}_{\text {hitung }}<\mathrm{t}_{\text {tabel }}$ atau $(-1,4809<2,306)$. Return On Asset tidak berpengaruh signifikan terhadap Debt to Equity Ratio dengan kontribusi pengaruh sebesar 13,9\%. Uji hipotesis diperoleh nilai $\mathrm{t}_{\text {hitung }}$ $<\mathrm{t}_{\text {tabel }}$ atau $(-1,138<2,306)$. Current Ratio dan Return On Asset berpengaruh signifikan terhadap Debt to Equity Ratio dengan kontribusi pengaruh sebesar 39,2\% sedangkan sisanya sebesar 60,8\% dipengaruhi faktor lain. Uji hipotesis diperoleh nilai $\mathrm{F}_{\text {hitung }}<\mathrm{F}_{\text {tabel }}$ atau $(2,259<4,350)$.

\section{PENGHARGAAN}

Puji syukur saya panjatkan kepada Allah SWT, yang telah melimpahkan Rahmat, Taufiq serta Hidayah-Nya sehingga saya dapat menyelesaikan jurnal berjudul : "Pengaruh Likuiditas dan Profitabilitas Terhadap Sruktur Modal Pada PT Duta Anggada Realty Tahun 20082017". Semoga melalui tulisan ini saya dapat melanjutkan penulisan yang berkaitan dengan konsentrasi keuangan sehingga ilmu yang didapat bisa saya bagi melalui Jurnal Madani. Selain itu saya ucapkan terima kasih kepada ibu saya $\mathrm{Hj}$. Sri Kismani, adik saya Dewi Iriani, teman-teman dosen di antaranya Ibnu Sina, Janudin, dan Jasmani serta mahasiswa yang men-support untuk menulis tentang Ilmu Ekonomi yang berfokus pada bidang keuangan. Semoga ilmu yang saya dapatkan dan saya bagi pada Jurnal Madani bermanfaat bagi para peneliti, dosen, maupun mahasiswa yang membacanya. Akhir kata saya ucapkan terima kasih.

\section{DAFTAR PUSTAKA}

Arta, Y. K. (2013). Pengaruh Penanaman Modal Asing (PMA), Penanaman Modal Dalam Negeri (PMDN) dan Angkatan Kerja Terhadap Pertumbuhan Ekonomi 
di Jawa Tengah. Jurnal Analisis Ekonomi Pembangunan. Vol. 2 No. 2.

Arikunto, S. (2014). Prosedur Penelitian Suatu Pendekatan Praktik. Jakarta: Rineka Cipta.

Bambang, R. (2011). Dasar-dasar Pembelanjaan Perusahaan. Edisi ke Empat. Yogyakarta: BPFE.

Brealey, R.A. Myers, S.C., Marcus, A.J. (2012). Fundamentals of Corporate Finance Seventh Edition. United States: The McGraw-Hill Companies, Inc.

Brigham, H. (2011). Dasar-Dasar Manajeman Keuangan Buku 2 Edisi 11.

Darsono dan Ashari. (2010). Pedoman Praktis Memahami Laporan Keuangan. Yogyakarta: Andi.

Mahendra, Alfredo, Dj., Luh.G.S.T dan A.A. G. S. (2012). "Pengaruh Kinerja Keuangan terhadap Nilai Perusahaan Pida Perusahaan Manufaktuur di BEI". Jurnal Manajemen, Strategi Bisnis, dan Kewirausahaan, Vol. 6 No. 2 Bali: Universitas Udayana.

Mardinawati. (2011). Faktor-Faktor yang Mempengaruhi Struktur Modal Pada Perusahaan Otomotif yang Terdaftar di BEI. Jurnal Administrasi Bisnis. 12 (3), pp : 1-10.

Martono dan Agus, H. (2011). Manajemen Keuangan. Jakarta: Penerbit Ekonisia.

Prasinta, D. (2012). Pengaruh Good Corporate
Governance Terhadap Kinerja Keuangan, Accounting Analysis Jurnal 2 (1). 4-17.

Primantara, D.Y. dan Made R.D. (2016). "Jurnal Pengaruh likuiditas, profitabilitas, Risiko bisnis, ukuran perusahaan, dan Pajak terhadap struktur modal", Universitas Udayana, Bali.

Riyanto, B. (2010). Dasar-Dasar Pembelanjaan Perusahaan, ed. 4. Yogyakarta: BPFE.

Sarlija, N. dan Harc, M. (2012). The Impact of Liquidity on The Capital Structure: a Case Study European Countries. Innternasional Couunccil for Small Business World Conference, p.1-49.

Santoso, S. (2015). Menguasai Statistik Multivariat. Jakarta: PT Elex Media Komputindo.

Siregar. A. (2012). Pengaruh Struktur Modal Terhadap Aktivitas Operasi pada Perusahaan Manufaktur di Bursa Efek Indonesia. Jurnal Visioner dan Strategis Vol.1, No.2. ISSN.

Sugiyono. (2017). Metode Penelitian Administrasi: dilengkapi dengan Metode $R$ \& $D$. Bandung: Alfabeta.

Tangkulung, E. G., Sri M., dan Victoria, N. U. (2019). Jurnal Pengaruh Asset Size dan Profitabilitas Terhadap Struktur Modal Pada Perusahaan Real Estate dan Property yang Terdaftar di BEI Periode 2013-2016. 